THE TERRY LECTURES

Against Dharma 
VOLUMES IN THE TERRY LECTURES SERIES

AVAILABLE FROM YALE UNIVERSITY PRESS

The Courage to Be Paul Tillich

Psychoanalysis and Religion Erich Fromm

A Common Faith John Dewey

Psychology and Religion Carl G. Jung

Belief in God in an Age of Science John Polkinghorne

One World Now: The Ethics of Globalization Peter Singer

Reason, Faith, and Revolution: Reflections on the God Debate Terry Eagleton

Thinking in Circles: An Essay on Ring Composition Mary Douglas

The Religion and Science Debate: Why Does It Continue? Edited by Harold W. Attridge

Natural Reflections: Human Cognition at the Nexus of Science and Religion Barbara Herrnstein Smith

Absence of Mind: The Dispelling of Inwardness from the Modern Myth of the Self Marilynne Robinson

Islam, Science, and the Challenge of History Ahmad Dallal

The New Universe and the Human Future: How a Shared Cosmology Could Transform the World Nancy Ellen Abrams and Joel R. Primack

The Scientific Buddha: His Short and Happy Life Donald S. Lopez, Jr. Life After Faith: The Case for Secular Humanism Philip Kitcher Private Doubt, Public Dilemma: Religion and Science since Jefferson and Darwin Keith Thomson

For a full list of titles in print in the Terry Lectures Series, visit yalebooks.com or yalebooks.co.uk. 


\title{
Against Dharma
}

Dissent in the Ancient Indian Sciences of Sex and Politics

\author{
WENDY DONIGER
}

Yale UNIVERSITY PRESS

New Haven and London 
Published with assistance from the Louis Stern Memorial Fund.

Copyright $\odot 2018$ by Wendy Doniger.

All rights reserved.

This book may not be reproduced, in whole or in part, including illustrations, in any form (beyond that copying permitted by Sections 107 and 108 of the U.S. Copyright Law and except by reviewers for the public press), without written permission from the publishers.

Yale University Press books may be purchased in quantity for educational, business, or promotional use. For information, please email sales.press@yale.edu (US office) or sales@yaleup.co.uk (UK office).

Set in Minion type by Newgen North America.

Printed in the United States of America.

Library of Congress Control Number: 2017952014

ISBN 978-0-300-21619-6 (hardcover : alk. paper)

A catalogue record for this book is available from the British Library.

This paper meets the requirements of ANSI/NISO Z39.48-1992 (Permanence of Paper).

10987654321 
THE DWIGHT HARRINGTON TERRY FOUNDATION LECTURES ON RELIGION IN THE LIGHT OF SCIENCE AND PHILOSOPHY

The deed of gift declares that "the object of this foundation is not the promotion of scientific investigation and discovery, but rather the assimilation and interpretation of that which has been or shall be hereafter discovered, and its application to human welfare, especially by the building of the truths of science and philosophy into the structure of a broadened and purified religion. The founder believes that such a religion will greatly stimulate intelligent effort for the improvement of human conditions and the advancement of the race in strength and excellence of character. To this end it is desired that a series of lectures be given by men eminent in their respective departments, on ethics, the history of civilization and religion, biblical research, all sciences and branches of knowledge which have an important bearing on the subject, all the great laws of nature, especially of evolution ... also such interpretations of literature and sociology as are in accord with the spirit of this foundation, to the end that the Christian spirit may be nurtured in the fullest light of the world's knowledge and that mankind may be helped to attain its highest possible welfare and happiness upon this earth." The present work constitutes the latest volume published on this foundation. 
This page intentionally left blank 